\title{
POLEMIKA WLADYSLAWA KONOPCZYŃSKIEGO Z MIECZYSŁAWEM SKIBIŃSKIM
}

W 1911 r., po konflikcie z Szymonem Askenazym, Władysław Konopczyński ograniczył swoje kontakty ze Lwowem, a niechęć do byłego mistrza przeniósł też na jego uczniów, m.in. Adama Skałkowskiego, Emila Kipę, Kazimierza Mariana Morawskiego, a przede wszystkim Mieczysława Skibińskiego, o którego zdolnościach naukowych miał bardzo złe mniemanie. Po latach przeszkodził mu w zrobieniu habilitacji. Skibińskiego poznał we Lwowie za pośrednictwem Oswalda Balzera w październiku 1909 r. ${ }^{1}$ Do bliższego kontaktu doszło jednak dopiero w lutym 1911 r. w Krakowie. Wtedy uczony z przekąsem wyraził się o Skibińskim, że to „paradny facet; trochę mi go żal”2. Kolejne spotkanie odbyło się w lipcu 1912 r., kiedy Skibiński drukował dwutomowe dzieło pt. Europa a Polska $w$ dobie wojny o sukcesje austriacka w latach 1740-1745, t. 1-2, Kraków 1912-1913³. Praca ta została przyjęta 24 czerwca 1912 r. jako doktorat na Wydziale Filozoficznym Uniwersytetu Jagiellońskiego ${ }^{4}$. Zaraz po wyjściu książki z drukarni, Konopczyński zabrał się do lektury. Z początku nie był „ani oczarowany, ani rozczarowany"'. W trakcie czytania odwiedził go Skibiński, który radził się, „,co opracować w dalszym ciągu: czy posunąć się w lata 1746-1751, czy też przejść do wieku XIX”. Po namyśle Konopczyński „,nie odradzał pierwszego, chociaż te lata” były przez niego „dość mocno zorane”, ale ,jeszcze bardziej namawiał na bezkrólewie po Sobieskim" ". Pomimo osobistych kontaktów ze

\footnotetext{
${ }^{1}$ W. Konopczyński, Dzienniki, rkps w Archiwum Rodziny Konopczyńskich w Warszawie (dalej: ARKW), z. 46, s. nlb., zapis z 23 X 1909 r. Zob. też Biblioteka Zakładu Narodowego im. Ossolińskich (dalej: BO), rkps 7689. List M. Skibińskiego do O. Balzera, Sambor 14 X 1909 r.

${ }^{2}$ W. Konopczyński, Dziennik, rkps w ARKW, z. 49, s. nlb., zapis z 28 II 1911 r.

${ }^{3}$ Tamże, z. 54, s. nlb. zapis z 9 VII 1912 r.

${ }^{4}$ Archiwum Uniwersytetu Jagiellońskiego (dalej: AUJ), WF II 504. Teczka doktorska M. Skibińskiego.

${ }^{5}$ W. Konopczyński, Dziennik, rkps w ARKW, z. 56, s. nlb., zapis z 7 V 1913 r.

${ }^{6}$ Tamże, 29 VI 1913 r. Stąd trzy powyższe cytaty.
} 
Skibińskim, Konopczyński patrzył na jego dzieło coraz surowiej, często notował „na marginesie sporo rzeczy do skrytykowania"7.

W styczniu 1914 r., po przeczytaniu pierwszego tomu, doszedł do przekonania, że książkę Skibińskiego należy krytycznie zrecenzować na łamach „Kwartalnika Historycznego". Przed zabraniem się do pisania „ogromnej recenzji [...],

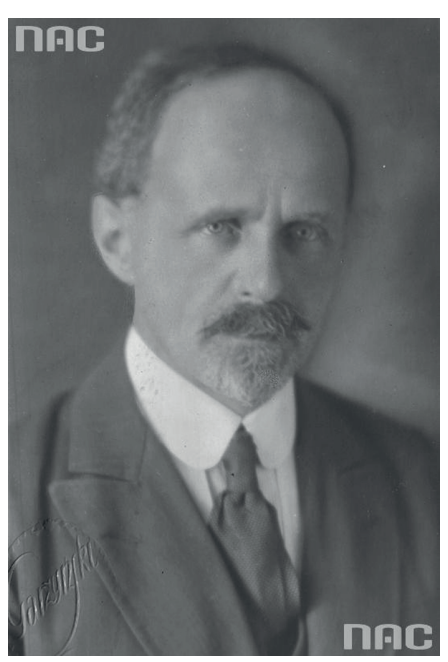

Ryc. 1. Władysław Konopczyński (NAC)

wieczorami na zaśnięcie" czytał drugi tom dzieła, będący edycją źródłową ${ }^{8}$. W dzienniku wspomniał, że Skibińskiego „ogryzał tak sumienie, jak nikogo przedtem”. „Recenzja będzie ogromna i pomimo najlepszych z mej strony chęci, naganna" - konstatowa ${ }^{10}$. Na pisanie recenzji poświęcał wiele godzin „odnotowując w różnych ugrupowaniach błędy”" Zgodność edycji źródłowej diariusza sejmu z 1744 r., zamieszczonego w drugim tomie dzieła Skibińskiego, sprawdzał z oryginałem w Bibliotece Czartoryskich. „Różnice były ogromne - stwierdził z irytacją - trzeba będzie przez kogoś to wydać na nowo". Wykryte, rażące błędy, zmusiły Konopczyńskiego do jeszcze większego zaangażowania, tak że „cały prawie wolny czas” spędzał nad Skibińskim, zawsze miał go „na noc przy łóżku, jak kasztelanowa kamieńska [tj. Katarzyna z Potockich Kossakowska] starego Fryca"12. Recenzja rozwlekła się do ponad 20 stron; autor zastanawiał się, ,jak zrobić, żeby się nie wydać okrutnikiem, kiedy chwilami difficile est satyram non scribere?"13.

Pod koniec marca 1914 r., gdy tekst był już prawie gotowy, Konopczyński stwierdził, że recenzja kosztowała go „111/2 miesiąca pracy. Różne drobiazgi mogą się opłacić, ale w sumie są zdawkową monetą. Już to widać, że ani Rady Nieustającej, ani veto nie wykończę przed przyszłym rokiem" ${ }^{14}$. W recenzji pojawiło się kilka przytyków do prac Askenazego, choć Skibiński był z nim już od kilku lat skonfliktowany ${ }^{15}$. Po złożeniu recenzji do druku, Konopczyński ciągle wracał

\footnotetext{
${ }^{7}$ Tamże, z. 57, s. nlb., zapis z 5 IX 1913 r.

${ }^{8}$ Tamże, z. 58, s. nlb., zapis z 28 I 1914 r.

${ }^{9}$ Tamże, 30 I 1914 r.

${ }^{10}$ Tamże, 6 II 1914 r.

${ }^{11}$ Tamże, 8 II 1914 r.

${ }^{12}$ Tamże, 9 II 1914 r. Stąd trzy powyższe cytaty.

${ }^{13}$ Tamże, 17 II 1914 r.

${ }^{14}$ Tamże, 20 III 1914 r.

${ }^{15}$ Biblioteka Naukowa Polskiej Akademii Umiejętności i Polskiej Akademii Nauk w Krakowie (dalej: BN PAU i PAN Kr), rkps 2402, t. 3, k. 89-91. List M. Skibińskiego do B. Ulanowskiego, Sambor 14 VI 1909 r. „Wobec prof. Askenazego nie zaciągnąłem żadnego formalnego zobowiązania i nie popełniłem nigdy żadnej niewłaściwości. Zapowiedział mą pracę w swych «Monografiach»
} 
do książki Skibińskiego. W dzienniku żartobliwie wspominał: „nigdy z tobą rozstać się nie mogę"16. W czasie pobytu autora w Szwecji recenzja ukazała się na łamach „Kwartalnika Historycznego"17. Po wojnie Skibiński odpowiedział na nią na łamach „Kwartalnika Historycznego"18.

Wojna przerwała na kilka lat kontakty obu historyków. Dopiero w połowie 1919 r. ich relacje uległy odnowieniu, podczas starań Skibińskiego o uzyskanie habilitacji. 25 czerwca 1919 r. Rada Wydziału Filozoficznego Uniwersytetu Jagiellońskiego odrzuciła jego wniosek o dopuszczenie do habilitacji ze względu na to, że jej podstawą miała być ta sama praca, za którą uzyskał on stopień doktora $^{19}$. W dzienniku Konopczyński wspominał: „,był u mnie Mieczysław Skibiński w sprawie habilitacji, z trudnością odłamałem się od nieprzyjaciela, dowodząc,

bez mej wiedzy, mimo, iż przed wyjazdem do Berlina w listopadzie 1908 roku, wyraźnie, u niego w domu we Lwowie oświadczyłem mu, iż nie może zapowiadać miej pracy tak długo, dopóki nie będzie gotowa. Wycofałem się, ponieważ prof. Askenazy dal mi tyle dowodów niechęci w stosunku do mej pracy, że już wtedy w listopadzie tego roku postanowiłem usunąć się spod wszelkich jego wpływów. Nikt nie dałby wiary, a jednak jest to niestety faktem, że prof. Askenazy nie znosi, aby praca ucznia stawała na wysokości swego zadania, z obawy, aby Broń Boże uczeń nie przewyższył swego mistrza. Niechciał np., abym udał się do Wiednia i Berlina - pojechałem wbrew jego woli - w niczym nie dopomógł mi do otrzymania urlopu, co najważniejsze, - za co do niego mam żal głęboki - nie udzielił mi żadnej wskazówki, gdy w jesieni 1907 roku po raz pierwszy wybrałem się do Drezna. A wszakże prof. Askenazy jest znawcą epoki saskiej w Polsce i mógł, gdyby chciał, dać mi wystarczające informacje, bez których praca moja w archiwach była bardzo mozolna i powolna. Ile poszło czasu na marne, zanim opanowałem materiał i zorientowałem się w sytuacji, zbyteczna wspominać. Po prostu prof. Askenazemu chodzi tylko o to, aby tych tomików «Monografii» było jak najwięcej, ma to być robota ot byle jaka, kompilatorska, byle niewielka, a stanowiła tomik! Ja do takiej roboty i do takiego kierownika mam wstręt i wśród takich warunków wspólna dalsza praca jest niemożliwa. Zresztą nie jestem odosobniony, wszyscy dawniejsi uczniowie prof. Askenazego usunęli się od niego, Loret, Pawłowski, Piotrowicz, inni. Prof. Askenazy podkreśla swe zdolności przy każdej sposobności, wynosi swe zasługi pod niebiosy, z przekąsem mówi o swych kolegach uniwersyteckich o Akademii Umiejętności wyraził się, że wydaje «tomy, których nikt nie czyta» aluzja do obszernych wydawnictw Akademii. Usposobienie jego, jego sarkazm i jego niezwykła pycha odsunęły od niego jego uczniów. Mimo wszystko, mimo to całe moje wyjaśnienie, które tylko z konieczności dać musiałem, gotów jestem oddać mą pracę prof. Askenazemu, jeśli JW. Pan Profesor uzna, że ja tak powinienem uczynić, choćby dlatego, że wycofałem się za późno nieco! Ośmielam się jednak dodać, iż na żądanie Akademii Umiejętności nie sądzę, aby prof. Askenazy sprzeciwiał się dłużej ogłoszeniu mojej pracy w wydawnictwa Akademii. Gdyby więc JW. Pan Profesor raczył sam od siebie zapytać się prof. Askenazego, czy ma co przeciw mnie, przeciw ogłoszeniu mej rozprawy przez Akademię, sądzę, że byłby to środek najprostszy, gdyż ma mój list polecony ze stycznia br. Prof. Askenazy żadnej nie dał mi odpowiedzi i obecnie nie odpowiedziałby mi. Wskutek tego nie mógłbym dać owej deklaracji prof. Askenazego".

${ }^{16}$ W. Konopczyński, Dziennik, rkps w ARKW, z. 60, s. nlb., zapis z 4 IX 1914 r.

${ }^{17}$ W. Konopczyński, [rec.] M. Skibiński, Europa a Polska $w$ dobie wojny o sukcesję austriacka w latach 1740-1745, „Kwartalnik Historyczny”, R. 28, 1914, s. 227-254.

${ }^{18}$ M. Skibiński, Polemika, „Kwartalnik Historyczny”, R. 33, 1919, s. 196-205. W. Konopczyński, Polemika, „Kwartalnik Historyczny”, R. 33, 1919, s. 205-206. Zob. też AUJ, sygn. 126/13. List M. Skibińskiego do T.E. Modelskiego, Kraków 6 V 1919 r.

${ }^{19}$ AUJ, WF II 121. Teczka habilitacyjna M. Skibińskiego. Zob. też Z. Zielińska, Skibiński Mieczysław, Polski Słownik Biograficzny, t. 38, 1997-1998, s. 138-139. 
że nie mogę przyjąć rozprawy doktorskiej (Europa a Polska) za habilitacyjną, skoro Wydział uchwalił takich rozpraw nie przyjmować. Radziłem mu, by się zabrał do pisania czegoś nowego"20. Pod wpływem sugestii Konopczyńskiego „Skibiński już zrezygnowany” doszedł do wniosku, że „trzeba będzie pisać nową rozprawę”. Profesor zaproponował mu „«Francję i Polskę 1684-1696» według [Kazimierza] Waliszewskiego i moich notatek". Jednak sceptycznie zaznaczał, że „nie widzi, żeby się z tem uporał”21. Prognozy Konopczyńskiego nie okazały się słuszne, gdyż Skibiński napisał w latach 1920-1924 rozprawę habilitacyjną pt. Polityka Jana III w latach 1674-1683.

Do kolejnego spotkania zwaśnionych historyków doszło podczas posiedzenia krakowskiego Koła Polskiego Towarzystwa Historycznego. Konopczyński wspominał: „O 6-ej było zebranie historyków. Skibiński wygłosił swoje głupstwo o sejmie [grodzieńskim] r. 1744. Krytykowałem łagodnie, aby nie robić przykrości obecnej na sali rodzinie prelegenta. Ów nie zrozumiał i wystąpił z pretensjami do [Fryderyka] Papéego, czemu mnie nie przerywał! Takiego ananasa jeszcześmy nie mieli”22. Kilka dni po przykrym zajściu „Kutrzeba interpelował mnie, po co się znęcam nad Skibińskim. Podobno ten zrobił już nawet hałas w Kurierku"²3. Aby załagodzić sytuację i „dogodzić pretensjom obecnego [na posiedzeniu Koła PTH] Skibińskiego”, Konopczyński oświadczył, że „nie zamierzał go pomawiać o szerzenie poglądów Ostmarkenverinu”. Jednak ,zaraz potem wyraził życzenie, żeby nasze zebrania nie budziły takich odgłosów, jak wiadoma notatka w Kurierku (którą przytoczyłem). Prezydium zadrżało, czy nie będzie awantury..."24.

Wystąpienie Konopczyńskiego spotkało się z ostrą reakcją Skibińskiego, który polemizował z nim na łamach „Kwartalnika Historycznego”. Redaktor czasopisma Ludwik Finkel przysłał ,artykuł polemiczny Skibińskiego - na ogół bardzo niemądry. Odpiszę mu. W paru drobnych szczegółach obronił się" - konstatował z irytacją Konopczyński ${ }^{25}$. Po opublikowaniu polemiki i repliki, konflikt pomiędzy obu historykami przybrał na sile. Gdy „Skibiński po ostatnim swoim odczycie w Kr[akowskim] Kole (o pierwotnej polityce Jana Sobieskiego)" zgłosił gotowość napisania rozdziału „do Składanych Dziejów Polski”, Konopczyński musiał sprowadzić go „na grunt smutnej rzeczywistości”"26. Ponadto starał się unikać jego odczytów i prelekcji. W dzienniku wspominał, że „Pan Skibiński dziś zaszczyca Akademię swoim referatem o polityce Sobieskiego. $\mathrm{N}+1$ powodów, aby świecić nieobecnością?"27.

\footnotetext{
${ }^{20}$ W. Konopczyński, Dziennik, rkps w ARKW, z. 74, s. nlb., zapis z 1 VII 1919 r.

${ }^{21}$ Tamże, 4 VII 1919 r.

${ }^{22}$ Tamże, z. 76, s. nlb., zapis z 13 XII 1919 r.

${ }^{23}$ Tamże, 27 XII 1919 r.

${ }^{24}$ Tamże, 24 I $1920 \mathrm{r}$.

${ }^{25}$ Tamże, 19 II $1920 \mathrm{r}$.

${ }^{26}$ Tamże, z. 81, s. nlb., zapis z 18 VI $1921 \mathrm{r}$. Stąd trzy powyższe cytaty.

${ }^{27}$ Tamże, z. 82, s. nlb., zapis z 17 X 1921 r.
} 
Sprawa konfliktu na pewien czas przycichła, aby w 1926 r. wybuchnąć na nowo. Miało to związek z ponownymi staraniami Skibińskiego o habilitację na podstawie rękopisu pt. Polityka Jana III w latach $1674-1683^{28}$. Praca ta nie została nigdy wydana, ponieważ najpierw władze Kasy im. Józefa Mianowskiego, a później PAU, na skutek negatywnej opinii Konopczyńskiego, odmówiły publikacji, pomimo w miarę pozytywnych recenzji Jana Feliksa Jakubowskiego i Stanisława Zakrzewskiego ${ }^{29}$. Należy jednak pamiętać, że obie recenzje były mało miarodajne, gdyż Jakubowski był specjalistą od dziejów Litwy, a Zakrzewski mediewistą. Ponadto Zakrzewski w swojej ocenie nie był jednoznaczny. Po pierwsze uważał, że obszerny maszynopis liczący 1400 stron należałoby skrócić o połowę. Po drugie postulował skreślenie ,zbyt drastycznych charakterystyk; obszerny zatem ustęp w przedmowie, poświęcony różnym pracom prof. Konopczyńskiego, powinien być skreślony, a to tym bardziej, że luźno tylko łączy się z treścią samej przedmowy. Po trzecie usuniecie fragmentów rażących jednostronnością i subiektywizmem. Sumując stwierdził, że „prof. Skibiński włożył tyle pracy, że winno

${ }^{28}$ Rękopis pracy znajduję się w Archiwum Nauki Polskiej Akademii Nauk i Polskiej Akademii Umiejętności w Krakowie (dalej: AN PAN i PAU Kr), K III-71/2.

${ }^{29}$ BO, rkps 7349. List M. Skibińskiego do S. Zakrzewskiego, Kraków 20 II 1926 r. „W drugiej połowie września oddałem Akademii moją pracę na jej wyraźne życzenie. Wobec tego, że rękopis mój odleżał się już cały rok z górą w Warszawie, a prof. Jakubowski, referent mej pracy, wyraził się o niej bardzo przychylnie, miałem prawo oczekiwać, że nowa ocena mej pracy nastąpi rychło i że wreszcie rozpocznie się jej druk. Musze bowiem dodać, że właśnie dobiegają już dwa pełne lata (1 marca b.r.), jak po raz pierwszy oddałem mą pracę Akademii, więc już czas najwyższy, aby się rozpoczął jej druk. Dlatego najusilniej proszę JW. Pana Profesora, aby raczył łaskawie, przyspieszyć ocenę mej pracy, którą czytał już i prof. Sobieski i prof. Jakubowski. Wszak moja praca była już przyjęta przez Komitet Kasy Mianowskiego do druku, a tylko wskutek intryg prof. Konopczyńskiego została mi zwróconą. W Warszawie pan Konopczyński mógł mi szkodzić, ale wpływy jego nie sięgają aż do Lwowa, więc mimo, iż upłynęło sporo czasu, jak Akademia wysłała mój rękopis JW. Panu Profesorowi, wierzę w to, że ocena mojej pracy wkrótce nadejdzie i że moja dobra sprawa odniesie druzgocące zwycięstwo nad intrygami i nepotyzmem". BN PAU i PAN Kr, rkps 2572, t. 2, k. 67-68. List M. Skibińskiego do J.M. Rozwadowskiego, Kraków 14 X 1926 r. „W marcu 1924 roku oddałem mój rękopis do rąk Akademii. Niestety Akademia nie miała wtedy pieniędzy i dlatego za jej wiedzą i radą wysłałem mą pracę do Kasy im. Mianowskiego w Warszawie. Praca moja została przyjęta do druku na podstawie jej oceny, dokonanej przez prof. Jakubowskiego. Dowiedział się o tem prof. Konopczyński (szwagier prof. Lutostańskiego, prezesa Kasy), który swymi intrygami spowodował zwrot rękopisu w czerwcu 1925 roku. Prof. Konopczyński uczynił to z zemsty za niepochlebną opinię, jaka umieściłem o jego pracach o Sobieskim w przedmowie do mej pracy. Na wiadomość o tym przyjęła Akademia zpowrotem mą pracę (wrzesień 1925 roku) oddając ją do oceny prof. St. Zakrzewskiego we Lwowie. Od tego czasu nie otrzymałem od Akademii żadnej odpowiedzi na moje dwa pisma (ze stycznia i czerwca b.r.), chociaż prywatnie wiem już od prof. Zakrzewskiego, że praca moja znajduje się już w Krakowie wraz z bardzo pochlebną opinią. Na podstawie tych pochlebnych referatów prof. Jakubowskiego i prof. Zakrzewskiego miałem prawo oczekiwać, że Akademia zdecyduje się wreszcie na rozpoczęcie druku mej dwutomowej pracy, nad którą strawiłem pięć lat życia i która leży w rękopisie już dwa i pół roku. Mam wrażenie, że intrygi prof. Konopczyńskiego sięgają aż do Akademii, gdzie go wspiera przyjaciel jego prof. Kutrzeba. Dlatego najuprzejmiej upraszam JW. Pana Prezesa, aby z urzędu swego raczył łaskawie uwzględnić tę sprawę i poświęcić chwilę mej pracy". 
się ją choćby tylko technicznie doprowadzić do końca. Jako nie specjalista nie śmiem orzekać, czy nie należy samych poszukiwań uzupełnić materiałami warszawskimi, zwłaszcza po powrocie materiałów petersburskich i moskiewskich" 30 .

Po zapoznaniu się z recenzją Zakrzewskiego, dyrektor Wydziału II, Władysław Semkowicz zamówił trzecią recenzję u Józefa Feldmana, który w jedenastostronicowej recenzji jednoznacznie stwierdził, że praca nie nadaje się do druku. Za najważniejsze mankamenty pracy recenzent uznał błędy metodologiczne i merytoryczne. Jego zdaniem ,autor obchodził się ze źródłami w sposób zupełnie dowolny”. Wygłaszał swoje „,banalne i naiwne” sądy „,w sposób niezwykle apodyktyczny, nie uważał jednak za właściwe poprzeć je jakimikolwiek dowodzeniami, ani w ogóle nadać im cechy prawdopodobieństwa”. „Konstrukcja pracy jest banalna i chaotyczna - pisał Feldman - autor powtarza te same rzeczy po kilka i kilkanaście razy, przeplata ustawicznie tok opowiadania moralizowaniem lub inwektywami”. Szczególnie nieprzyjemną krytyką dotknął Konopczyńskiego zarzucając mu „streszczanie dzieł cudzych” i „wstręt niekłamany” do rzetelnej pracy badawczej ${ }^{31}$.

Według Skibińskiego, Konopczyński miał się na nim mścić za postawiony mu w przedmowie zarzut plagiatu dwóch rozdziałów pracy doktorskiej pt. Europa a Polska. Opinia ta odnosiła się do dwóch szkiców Konopczyńskiego pt. Polska $w$ dobie wojen śląskich i Fatalny sejm 1744, zamieszczonych w książce będącej zbiorem różnych publikowanych już wcześniej artykułów pt. Od Sobieskiego do Kościuszki. Szkice - drobiazgi - fraszki historyczne, Kraków 1921. Pełen poczucia krzywdy i zranionej ambicji, Skibiński groził prezesowi PAU Janowi Michałowi Rozwadowskiemu skierowaniem sprawy przeciwko Akademii na drogę sądową ${ }^{32}$. Przypominał też, że poprzedni sekretarz generalny PAU Stanisław Wróblewski oświadczył mu stanowczo: „Przyjmujemy Pańską pracę tylko dlatego, aby jej wyniki naukowe nie poszły na marne". Podnosił również, że Akademia „jest bowiem tylko włodarzem funduszów publicznych i w rozdziale ich nie wolno jej kierować się samowolą czy uprzedzeniem"33. Zarzuty Skibińskiego były

${ }^{30}$ AN PAN i PAU Kr, PAU W II-14. Recenzja S. Zakrzewskiego, Lwów 12 VII 1926 r.

${ }^{31}$ Tamże, Recenzja J. Feldmana, Kraków XI 1926 r.

${ }^{32}$ BN PAU i PAN Kr, rkps 2571, t. 2, k. 69-70. List M. Skibińskiego do J.M. Rozwadowskiego, Kraków 25 X 1926 r. „Przed tygodniem wysłałem obszerne pismo ze skargą na dziwne postępowanie Wydziału II. Dotąd nie otrzymałem odpowiedzi. Chcę wierzyć, że tylko poważne jakieś powody odroczyły ją na czas krótki. Sprawa moja jest jasna jak słońce i musi być rozstrzygnięta w duchu sprawiedliwości. Wydział II staje najwyraźniej po stronie prof. Konopczyńskiego i dlatego wstrzymuje mój rękopis nie bacząc na to, że dzieje mi się jawna krzywda. O ile więc JW. Pan Prezes nie zechce się zająć mą sprawą, będę zmuszony wbrew mym chęciom, poruszyć ją na drodze sądowej. Prof. Konopczyński bowiem dopuścił się plagiatu streściwszy dwa olbrzymie rozdziały z mojego dzieła «Europa a Polska» i ogłosił je jako własne szkice historyczne! Wspomniałem o tem (bardzo dyskretnie zresztą) w przedmowie do obecnej mej pracy i stąd jego nienawiść do mnie".

${ }^{33}$ AN PAN i PAU Kr, PAU W II-14. List M. Skibińskiego do Wydziału II Historyczno-Filozoficznego, Kraków 26 XI 1926 r. 
bezzasadne, gdyż władze PAU opierały się na recenzjach wydawniczych, natomiast Konopczyński w pierwszym ze szkiców z uznaniem wyrażał się o jego pracy doktorskiej. Uczony streszczając wywody Skibińskiego wskazywał co dla nauki wniósł doktorat, pomimo wykazanych wcześniej w recenzji błędów. Konopczyński chciał go dowartościować i dać mu satysfakcję. Skibiński tego nie zrozumiał, oskarżając go o popełnienie plagiatu ${ }^{34}$.

Pałający chęcią zemsty Skibiński, podczas posiedzenia krakowskiego Oddziału PTH, gdy uczeń Konopczyńskiego, Czesław Chowaniec wygłaszał referat na temat genezy kwestii wschodniej, „,nieprzyzwoicie i niemądrze zaatakował prelegenta - godząc oczywiście we mnie, że został odparty nie potrzebuję zaznaczać" - wspominał Konopczyński ${ }^{35}$.

Ich losy skrzyżowały się ponownie, gdy w marcu 1927 r., Kazimierz Chodynicki z Uniwersytetu Stefana Batorego w Wilnie zwrócił się do Konopczyńskiego z prośba o wyrażenie poufnej opinii o Skibińskim, który właśnie złożył podanie o otwarcie przewodu habilitacyjnego. Oczywiście ocena była negatywna i do habilitacji Skibińskiego w Wilnie nie doszło. Rozżalony, niedoszły habilitant, całą odpowiedzialność za ten fakt, zrzucił na Konopczyńskiego, uważając go „za swego prześladowcę". Rodzina Skibińskiego sądziła jednak, że w swych ocenach posuwa się on za daleko i ma „manię prześladowczą” na punkcie Konopczyńskiego ${ }^{36}$.

Podobnie negatywnie wyglądała sprawa z habilitacją Skibińskiego we Lwowie, gdzie za pośrednictwem Jana Ptaśnika i Stanisława Zakrzewskiego starał się on o przeprowadzenie postępowania habilitacyjnego ${ }^{37}$. Jednak na skutek negatyw-

${ }^{34}$ Z. Zielińska, Skibiński Mieczysław, Polski Stownik Biograficzny, t. 38, 1997-1998, s. 138-139.

${ }^{35}$ W. Konopczyński, Dzienniki, rkps w ARKW, z. 97, s. nlb., zapis z 19 VI 1926 r.

${ }^{36}$ Tamże, z. 100, s. nlb., zapis z 11 III 1927 r. Stąd powyższe dwa cytaty.

${ }^{37}$ Centralnyj Derżawnyj Istorycznyj Archiw u Lwowi (dalej: CDIAL), fond 711, op. 1, spr 120. List M. Skibińskiego do J. Ptaśnika, Kraków 4 III 1927 r. „Mam i drugą prośbę natury więcej już osobistej. Chciałbym się habilitować do historii powszechnej nowożytnej na podstawie mej pracy: Francja a Polska w latach 1674-1683, odbitka z «Przeglądu Powszechnego» luty 1927. Jest ona tylko streszczeniem mej dwutomowej pracy pt. Polityka Jana III w latach 1674-1683. Pracowałem nad nią kilka lat w Krakowie, Wiedniu i Berlinie. Akademia Umiejętności przyjęła ją była w roku 1924, ale dla braku pieniędzy odesłała ją do Warszawy. Kasa im. Mianowskiego przyjęła ją (referował ją prof. Jakubowski) i niebawem miał się rozpocząc jej druk, kiedy w cała tę sprawę wdał się prof. Konopczyński, który spowodował jej zwrot w czerwcu 1925 roku. Na wiadomość o tem przyjęła ją z powrotem Akademia dając ją do referatu prof. Zakrzewskiemu we Lwowie. W lipcu 1926 roku przyszła jego ocena do Krakowa a z końcem listopada tego samego roku Akademia zwróciła mi mój rękopis z lakonicznym dopiskiem: «Wydział II uchwalił nie drukować Pańskiej pracy». Prof. Wróblewski zostawszy ministrem wyjechał do Warszawy, a pp. Kutrzeba, Semkowicz i Konopczyński zrobili z mą pracą, co się im żywnie podobało. Z tych powodów nie chciałbym się habilitować w Krakowie. O ile więc moja prośba trafia do przekonania JW. Panu Dziekanowi, proszę najuprzejmiej o łaskawą odpowiedź. Do Lwowa wróciłbym z radością. Stosunki w Krakowie są istotnie nie do zniesienia - koterie, nepotyzm i grube nieuctwo święcą tu prawdziwy tryumf". BO, rkps 7349. List M. Skibińskiego do S. Zakrzewskiego, Kraków 24 III 1928 r. „Otrzymałem wczoraj pismo dziekana z dnia 10 b. m., zawierające nadzieję, że mogę być przypuszczony do habilitacji. Wiem, że w interesie mej sprawy dorzucił JW. Pan Prezes łaskawie kilka słów życzliwych. Są one dla mnie tym cenniejsze, ponieważ JW. Pan Prezes podjął się 
nej opinii Adama Szelągowskiego, władze Wydziału Humanistycznego Uniwersytetu Jana Kazimierza odrzuciły jego prośbę o dopuszczenie do habilitacji.

W swojej wrogości do Konopczyńskiego Skibiński był tak zacięty, że nikt z krakowskich historyków nie chciał go słuchać i nawet przychylni mu dotychczas Wacław Sobieski i Stanisław Zakrzewski zaczęli go unikać. Do kolejnego starcia między antagonistami, doszło podczas posiedzenia krakowskiego Oddziału PTH w październiku 1929 r. Skibiński wygłosił wtedy „płynnie, krótko i głupio” referat na temat Brandenburgii i Polski w drugiej połowie XVII w. Jego wystąpienie spotkało się z miażdżącą krytyką Konopczyńskiego i jego uczniów - Józefa Feldmana i Kazimierza Piwarskiego. Oburzony Skibiński zarzucił krytykom ignorancję i opuścił salę. Więcej już nie przemawiał, gdyż prezydium krakowskiego Oddziału PTH podjęło decyzję, aby go na posiedzenia nie zapraszać38.

Niezrażony tym Skibiński ponownie zwrócił się do Konopczyńskiego o pomoc w przeprowadzeniu habilitacji w Krakowie. Profesor był zażenowany, pisząc: „,co ja zrobię z tym Skibińskim co 2 lutego [1930] przesłał mi deklarację pokoju i zgody, bylebym go dopuścił do habilitacji. Nikt go nie chce"39. Na pojednawcze deklaracje Skibińskiego Konopczyński pozostał głuchy, a odpowiedź w sprawie habilitacji była negatywna, gdyż ,nikt jego habilitacji nie myśli przychylnie traktować, ani nawet Sobieski, który mu w oczy coś życzliwego mówił" ${ }^{40}$.

Odizolowany od środowiska naukowego, Skibiński, choć nie zrobił akademickiej kariery, to jednak nadal pracował naukowo, o czym świadczą dwa teksty wysłane do redakcji „Kwartalnika Historycznego” pt. Przymierze polsko-francuskie 1675 roku i Sejm koronacyjny w Krakowie 1676 roku ${ }^{41}$, zbiór trzech artykułów pod wspólnym tytułem Ze studiów nad wiekiem XVI i XVII wysłany do dyrektora Wydziału II Akademii Umiejętności Władysława Semkowicza ${ }^{42}$, a także referat pt. Poselstwo de Lesseins'a w Berlinie w latach 1661-62, wygłoszony w dniu 5 lutego 1938 r. w krakowskim Oddziale $\mathrm{PTH}^{43}$, prelekcja pt. Sejm walny

był tej żmudnej pracy przeczytania mego rękopisu! I właśnie tylko dzięki jego życzliwej o mej pracy opinii przypuszczony będę - wedle wszelkiego prawdopodobieństwa - do habilitacji”. CDIAL, fond 711, op. 1, spr 120. List M. Skibińskiego do J. Ptaśnika, Kraków 24 III 1928 r. „Wczoraj otrzymałem pismo dziekanatu Wydziału Humanistycznego wielce dla mnie życzliwe. Jest w nim wyrażona nadzieja, że mogę być przypuszczonym do habilitacji. Wiem, że JW. Pan Dziekan był łaskaw dorzucić do mej sprawy kilka słów życzliwych, za które jestem mu szczerze i mocno zobowiązany. Tymi dniami wysyłam do prof. Szelągowskiego mą pracę w rękopisie i dopiero na skutek jego o niej opinii wniosę podanie do Wydziału z prośbą o przypuszczenie mnie do habilitacji”.

${ }^{38}$ W. Konopczyński, Dziennik, rkps w ARKW, z. 108, s. nlb., zapis z 26 X 1929 r.

${ }^{39}$ Tamże, z. 109, s. nlb., zapis z 21 II 1930 r.

${ }^{40}$ Tamże, 7 III $1930 \mathrm{r}$.

${ }^{41}$ AUJ, sygn. 126/13. Listy M. Skibińskiego do T.E. Modelskiego, Kraków 30 I, 7 II, 24 II, 19 IV 1932, 11 I $1933 \mathrm{r}$.

${ }^{42}$ AN PAN i PAU Kr, PAU W II-15. Listy M. Skibińskiego do Wydziału II Historyczno-Filozoficznego, Kraków 29 XII 1933; 2, 3, I, 28 II, 9 IV, 13 VIII 1934;

${ }^{43}$ AN PAN i PAU Kr, PTH, K-9, j. a. 1. List M. Skibińskiego do S. Kutrzeby, Kraków 31 I 1938 r. List S. Kutrzeby do M. Skibińskiego, Kraków 3 II 1938 r. 
warszawski roku 1661, którą przedstawił na posiedzeniu Wydziału Filozoficzno-Historycznego PAU w dniu 25 kwietnia 1938 r., a także rękopis pracy pt. Ostatnie lata Jana Kazimierza 1660-1668, datowany na 25 listopada 1944 r. ${ }^{44}$ Zarobkowo poświęcał się pracy w gimnazjum św. Anny w Krakowie, a później w prywatnej szkole żeńskiej im. Emilii Plater w Sanoku. Po drugiej wojnie światowej, Skibiński choć nie był już czynny zawodowo, starał się wydać pozostające w rękopisie prace. $\mathrm{O}$ pomoc w ich publikacji zwrócił się do Konopczyńskiego, jednak i tym razem spotkał się z odmową ${ }^{45}$. Ostatnie lata życia spędził w Krakowie, gdzie zmarł w 1956 r. ${ }^{46}$ Taki był smutny finał konfliktu obu historyków.

Nie ulega wątpliwości, że w sporze tym Skibiński był stroną słabszą i miał niewielkie szanse w rywalizacji z niekwestionowanym autorytetem naukowym, jakim był Konopczyński. Zasadnicze znaczenie miała też determinacja uczonego w zwalczaniu Skibińskiego, wynikająca z niedopuszczalnego poziomu jego prac, a także ogromna zręczność w przekonywaniu środowiska naukowego do swoich racji. Nie ulega też wątpliwości, że kolejne prace Skibińskiego, nie spełniały wymogów stawianych rozprawom naukowym i nie kwalifikowały się do pozytywnej oceny w przewodzie habilitacyjnym. Dramatem Skibińskiego było to, że nie był on w stanie zrozumieć zasadności stawianych mu przez Konopczyńskiego zarzutów i poprawić swoich prac. Obok braków metodologiczno-warsztatowych i trudności w prawidłowej interpretacji źródeł, sprawę utrudniała konfliktowa natura Skibińskiego, przejawiająca się w groźbach skierowania sprawy do sądu, a także przerost ambicji naukowych nie odpowiadający rzeczywistym zdolnościom, powodujący postępującą depresję i nasilenie się stanów lękowych.

\section{Piotr Biliński}

\section{THE POLEMIC BETWEEN WLADYSLAW KONOPCZYŃSKI AND MIECZYSŁAW SKIBIŃSKI}

A famous polemic between Władysław Konopczyński and Mieczysław Skibiński took place in the interwar period in Cracow. Konopczyński in „Historical Quarterly” criticized Skibiński’s dissertation titled: Europe and Poland in the era of the War for the Austrian Succession in the years 1740-1745. After closing the polemic by the editors, the dispute between historians moved to the meetings of the Krakow branch of Polish Historical Society, Historical Commission of the Polish Academy of Sciences and the Faculty of Philosophy of the Jagiellonian University. After years Konopczyński prevented Skibiński from carrying out his habilitation process at the Jagiellonian University, which brought about his mental breakdown. After the Second World War, the conflict finally expired.

${ }^{44}$ Rękopis pracy znajduję się w AN PAN i PAU Kr, K III-71/1.

${ }^{45}$ List M. Skibińskiego do W. Konopczyńskiego, Kraków 11 V 1946, rkps w Archiwum Rodziny Konopczyńskich w Gliwicach.

${ }^{46}$ Z. Zielińska, Skibiński Mieczysław, Polski Słownik Biograficzny, t. 38, 1997-1998, s. 138-139. 